\title{
PYOPNEUMOTHORAX COMPLICATING RHEUMATOID LUNG DISEASE
}

\author{
BY \\ W. HINDLE AND D. A. H. YATES \\ From St. Thomas's Hospital, London
}

Specific lung changes occur in association with rheumatoid arthritis but rheumatoid lung nodules unassociated with pneumoconiosis are rare and there are very few reports of cavitation occurring in such nodules (Sieniewicz, Martin, Moore, and Miller, 1962; Noonan, Taylor, and Engleman, 1963; Dumas, Gregory, and Ozer, 1963; Locke, 1963; Yates, 1963).

This paper describes another patient in whom rheumatoid nodules were present and who developed a pyopneumothorax probably from cavitation of one of the nodules.

\section{Case Report}

A man aged 40 was admitted to hospital in April, 1963, with 18 months' intermittent joint pains involving his shoulders, knees, elbows, right ankle, and proximal interphalangeal joints. He had had rheumatic fever at the age of 16 and had been subject to Raynaud's phenomenon in cold weather. He had never been exposed to irritant dusts. He was thin and ill and had lost $21 \mathrm{lb}$. in weight. There was a small right pleural effusion, his liver was just palpable, and his fingers showed early clubbing.

Laboratory Investigations.-Haemoglobin $13 \cdot 2$ g. (90 per cent.); white blood cells 10,350 with a normal differential; erythrocyte sedimentation rate $22 \mathrm{~mm}$. in 1 hour; Waaler-Rose differential agglutination titre 1:32; latex slide test \pm . No antinuclear antibodies were found. No L.E. cells were seen. Plasma proteins and the electrophoretic pattern were normal.

$X$ rays of the involved joints were normal and there was no evidence of hypertrophic pulmonary osteoarthropathy. Chest $x$ ray showed no abnormality apart from the right pleural effusion. Bronchoscopy was normal. The pleural fluid was opaque but was sterile on culture on blood agar and Lowenstein's medium, and cn microscopy no neoplastic cells or stainable fat were found.

He was treated symptomatically and discharged with some improvement.

Progress.-In September, 1963, although his arthritis had remained quiescent, a chest $x$ ray showed an increase in the size of the right pleural effusion together with a rounded shadow in the right mid-zone. On tomography this opacity appeared to be fluid in the lesser fissure, but two rounded opacities were seen on the lateral aspect of the upper lobe (Fig. 1).

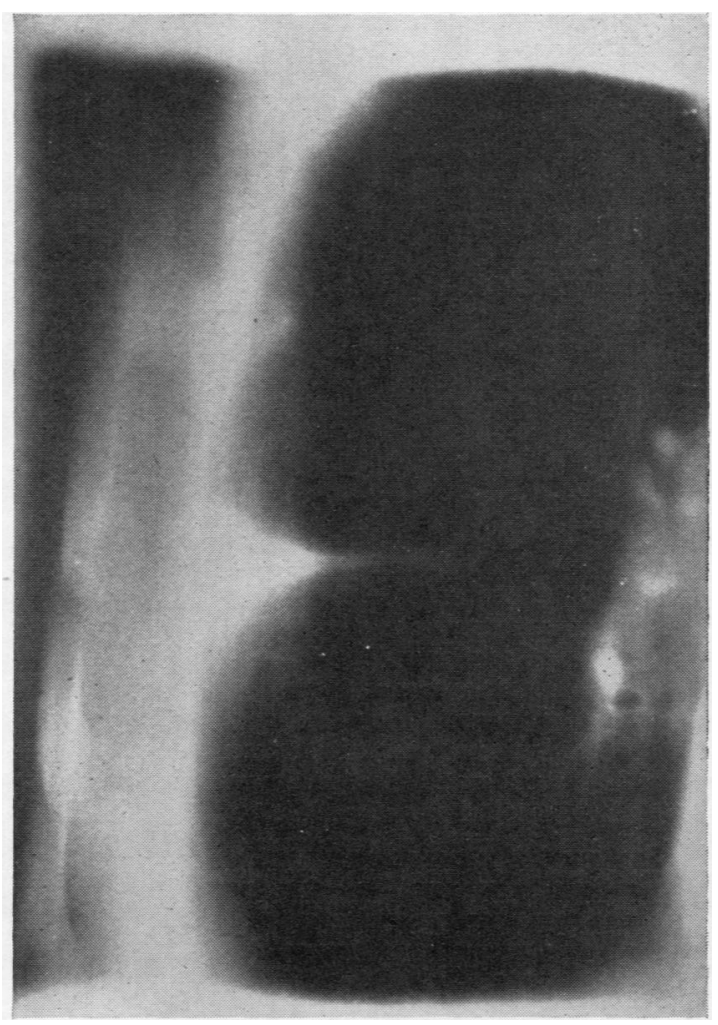

Fig. 1.-Tomogram of right lung, showing fluid in the lesser fissure and two pleural nodules. 


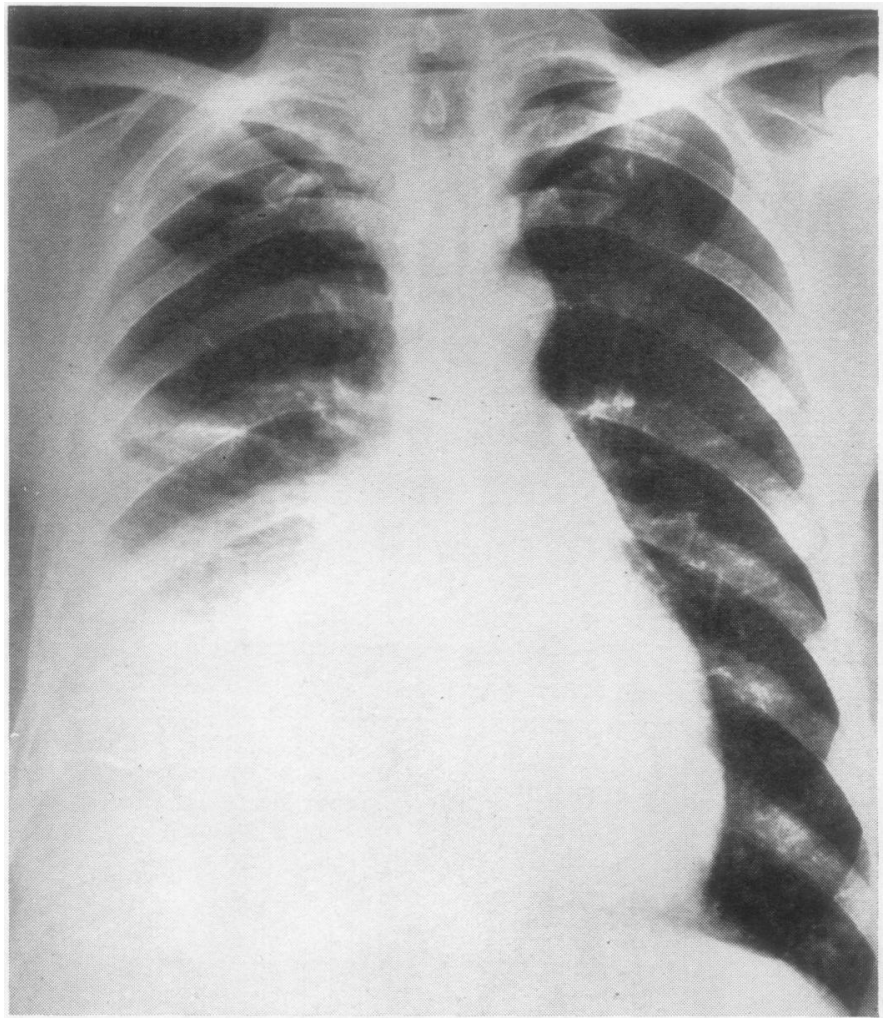

Fig. 2.- Postero-antero chest $x$ ray, showing a right pleural effusion and a cavitated right apical lesion.

A percutaneous pleural biopsy showed only nonspecific fibrosis, and at the same time an artificial pneumothorax was induced in an unsuccessful attempt to show the opacities more clearly. However, the lung re-expanded satisfactorily afterwards. The Waaler-Rose differential agglutination titre in the serum at this time was 1:64.

Six months later he developed a cough with purulent sputum, fever, left-sided pleuritic pain, herpes labialis, and crepitations over the anterior segment of the left upper lobe. Chest $x$ ray was normal on the left side but the right pleural effusion was larger and a cavitated area was seen at the right apex (Fig. 2).

Review of previous $x$ rays showed that this lesion was present 3 months previously although much smaller in size. Following treatment with tetracycline, the pneumonia improved gradually but 2 weeks later he was admitted to hospital severely short of breath and with signs of a right hydropneumothorax (Fig. 3). Thick creamy pus was aspirated in which no acid-fast bacilli were seen; cultures on blood agar and Lowenstein's medium were sterile and guinea-pig inoculation was negative.

Operation.-The lung did not re-expand satisfactorily with conservative measures, and in April a right thoracotomy was performed by Mr. Kent Harrison. At operation there was moderate thickening of the parietal and visceral pleura, but no evidence of an air leak was found, even on forcible re-expansion of the lung. There was a cluster of small white nodules on the visceral pleura and these appeared to involve lung tissue.

Histology.-A nodule was excised and histological examination showed a central area of necrosis surrounded by fibrous tissue containing chronic inflammatory cells tending to form a palisade layer (Fig. 4).

No giant cells, acid-fast bacilli, or fungi were seen and there was no evidence of polyarteritis. The appearances were considered to be similar to those described by Collins (1937) as typical of a subcutantous rheumatoid necrobiotic nodule.

\section{Discussion}

This case report shows how difficult it may be to diagnose rheumatoid lung disease. Initially it was thought that both the polyarthritis and pleural effusion might be due to a carcinoma of the bronchus; when a rounded opacity appeared on the chest $x$ ray 6 months later, the diagnosis of carcinoma seemed even more certain. As time passed the 




Fig. 3.-Postero-antero chest $x$ ray, showing a pyopneumothorax with residual right apical lesion.

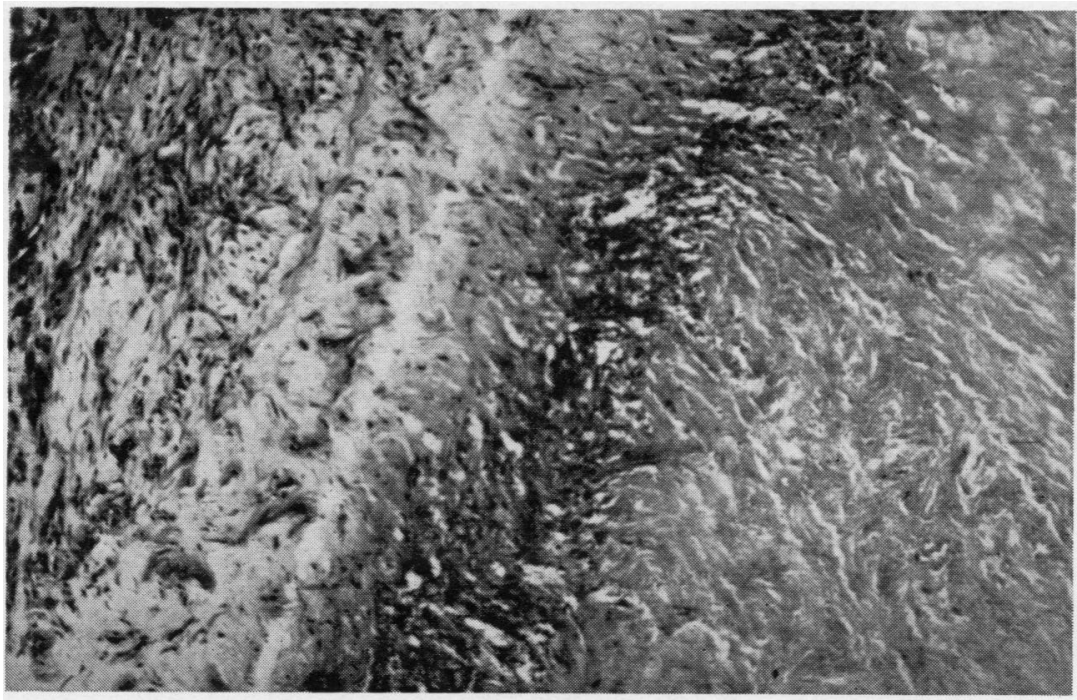

Fig. 4.-Photomicrograph from section of lung nodule, showing necrotic area bordered by chronic inflammatory cells tending to form a palisade layer. $\times 120$. 
likelihood that a bronchial carcinoma was responsible for his symptoms and signs became less, but it was only after a thoracotomy that this possibility could finally be discounted.

The development of a pyopneumothorax was obviously due to rupture of the lung. $X$ rays had shown the development of a cavitated lesion, but at operation there was no evidence of an abscess or cavitated tuberculosis. There was, however, a cluster of rheumatoid nodules at the right apex. It seems likely that the lesion seen on $x$ ray was a cavitated rheumatoid nodule which subsequently perforated into the pleural space giving rise to a pyopneumothorax.

\section{Summary}

The development of a spontaneous pyopneumothorax in a patient with rheumatoid arthritis and rheumatoid lung disease is recorded. It is suggested that rupture of a cavitated rheumatoid nodule was responsible for the development of this complication.

We should like to thank Dr. B. Creamer for permission to report this case.

\section{REFERENCES}

Collins, D. H. (1937). J. Path. Bact., 45, 97.

Dumas, L. W., Gregory, R. L., and Ozer, F. L. (1963). Brit. med. J., 1, 383.

Locke, G. B. (1963). Clin. Radiol., 14, 43.

Noonan, C. D., Taylor, F. B., Jr., and Engleman, E. P. (1963). Arthr. and Rheum., 6, 232.

Sieniewicz, D. J., Martin, J. R., Moore, S., and Miller, A. (1962). J. Canad. Ass. Radiol., 13, 73.

Yates, D. A. H. (1963). Ann. phys. Med., 7, 105.

Pyopneumothorax compliquant la maladie pulmonaire rhumatoide

RÉSUMÉ

On enregistre le dévéloppement d'un pyopneumothorax spontané chez un malade atteint d'arthrite rhumatismale et de maladie pulmonaire rhumatoïde. On pense que la rupture d'un nodule rhumatoïde cavitaire était responsable de cette complication.

Pioneumotorax complicando la enfermedad pulmonar reumatoide

Sumario

Se relata el desarrollo de un pioneumotorax espontáneo en un enfermo con artritis reumatoide y enfermedad pulmonar reumatoide. Se sugiere que la rotura de un nódulo reumatoide cavitario fué responsable de esta complicación. 